DOI: 10.20472/IAC.2018.040.044

\author{
SHEILA NOKUTHULA MATOTI \\ Central University of Technology, Free State, South Africa \\ BRIGITTE LENONG \\ Central University of Technology, Free State, South Africa
}

\title{
TEACHING LARGE CLASSES AT AN INSTITUTION OF HIGHER LEARNING IN SOUTH AFRICA
}

\begin{abstract}
:
In line with the notions of increased access to education as well as massification of education in South Africa and elsewhere, large classes have become common in Universities. While the size of a large class varies from country to country, in a South African context, and at our institution in particular, large classes can mean approximately 120 students in one seating. Although large classes can have a negative effect on student participation and engagement, especially when dealing with first year students, some strategies could be devised to deal with large classes. This study was undertaken to examine the problems students and lecturers experience in large classes as well as strategies that the lecturers have devised in promoting and sustaining student participation and engagement. The setting of the study is the Central University of Technology, Free State, an institution of Higher Learning in the Free State province of South Africa. The population for the study were first-year education students in 2017. A sample of 248 first year education students, from different areas of specialisation was used in the study. A self-constructed questionnaire was used to collect data from the students while semi-structured interviews were used to collect data from the lecturers. The findings revealed that large classes do pose challenges to both students and lecturers. However, both students and lecturers have developed strategies of dealing with large classes. Lecturers have resorted to team teaching, group assignments, and team marking. Students have benefitted from group assignments and group presentations as such activities afforded them opportunities to work collaboratively with one another. Although there is limited participation in class as there is no individual attention, within the groups, they are able to participate and engage with one another. The institution is charged with the responsibility to expand its facilities as the students cannot be turned away.
\end{abstract}

\section{Keywords:}

Large classes, engagement, lived experiences, pre-service students

JEL Classification: 123 


\section{INTRODUCTION}

The influx of first-year students at Higher Education Institutions (HEls) has resulted in large classes or overcrowding. The South African Department of Higher Education and Training (DHET) has put pressure on HEls to enrol as many students as possible (Hornsby, Osman \& De Matos-ala 2013). This is evident in the Green paper on post school education released in 2012 which states that universities in South Africa have to increase their intake from 900000 to 1,5 million by 2030 (RSA DHET 2012:20). Hence HEls are experiencing growth in students' enrolment. Hornsby at al. (2013) are of the view that large classes are depended on many factors such as the institution, class itself, discipline, and or pedagogical needs of the learning environment in the institution of higher education. A large class can be classified as a class of students between 60 to 149 and more than 150 students as a very large class (Moodley 2015). At the Central University of technology, Free State (CUT) large classes can mean approximately 120 students in one seating. Teaching large classes has a great impact on teaching and learning as it poses a threat on quality education which might result in poor performance (Moodley 2015; Hornsby at al. 2013; Mulryan- Kyne 2010). Delivering quality education to large classes and using effective teaching methods can be a challenge (Carpenter 2006; Mulryan- Kyne 2010). Hence the purpose of this article is to identify problems students and lecturers experience in large classes as well as effective strategies that lecturers have devised in promoting and sustaining student participation and engagement in large classes.

\section{RELATED LITERATURE}

\subsection{International perspective on large classes}

There are a vast number of studies conducted to examine teaching and learning in large classes at higher education institutions (Lloyd-Strovas 2015; Moodley 2015; Hornsby at al. 2013; Mulryan- Kyne 2010; Carpenter 2006; Cooper and Robinson 2000). In the United States, Carpenter (2006) used descriptive and inferential statistical techniques to examine the effectiveness of teaching methods for large classes and applied commonly used teaching methods; lecture, lecture discussion combination, jigsaw, case study and team projects in the study. This study revealed that colleges and universities in the United States are experiencing growth in student enrolment and undergraduate enrolment will continue to increase at a steady pace. The results showed that most students preferred to be taught in small class sizes and the lecture/discussion teaching method was the most preferred among students. This proves that students want to be active in the learning process rather than be passive. Active learning and lecture teaching methods can be a powerful tool for increasing student engagement (Lloyd-Strovas 2015; Mulryan- Kyne 2010; Carpenter 2006). The study done by Koenig, Gray, Lewis and Martin (2015) to investigate class size 
preferences of college students as well as reasons behind the preferences at the midsize state university on the east Coast is supportive to the fact that students preferred smaller classes more for major related courses than the general education and non-interesting required courses. Students had a strong preference for smaller classes for the following reasons; high levels of attention, better learning environment and lower levels of distraction (Koenig at al 2015).

A recent study done in Canada by Cash, Letargo, Graether and Jacobs (2017) analysed the perceptions and resources of large university classes indicated that enrolment in Canada in undergraduate postsecondary education has increased by up to 50\% between 2001 and 2011. Their results showed that instructor- students' interactions are not prevalent in large classes and instructor behaviour is an important contributor to student perception of a large class, in which a large class can begin at 240 students. In addition, they showed that scaling up or restructuring have been used to scale down large classes and came to a conclusion that making a class feel smaller requires the adjustments by the instructor and the course structure.

\subsection{South African perspective on large classes}

In South Africa the issue of large classes in Higher Education Institutions is not new. As alluded above universities are facing challenges presented by large classes (Moodley 2015; Hornsby at al. 2013; Jaffer, Ngambi \& Czerniewicz 2007). The study done by Onwu and Stoffel (2005) in one of the regions in South Africa, Limpopo, revealed that the issue of large classes is also experienced at schools. The study revealed that among other problems such as inadequate facilities, poorly qualified teachers, the 53 science teachers in the study, experienced increasing enrolment and overcrowded classes, and thus resorted to instructional functions dominated by lecturing. They further mentioned that teaching of large classes is at odds with professional competence required of teachers. Although their study focused on instructional functions in large, under-resourced science classes at schools, their study proves that the challenge of large classes emanates from lower grades in schools and as a result affects the intake of first-year students. Hence it is important to look into effective strategies that lecturers have devised in promoting and sustaining student participation and engagement in large classes.

Moodley (2015) examining the challenges faced by lecturers with large classes at higher education institutions and different approaches that are used to overcome the challenges at the University of Limpopo and university of Zululand in South Africa, came to the conclusion that large classes are more prevalent in first-year courses across most discipline. The study showed that lecturers did not prefer teaching large classes and used traditional lecture methods in their classes. Moodley (2015) further pointed out that in assessment the multiple-choice questioning was utilised mostly and this alleviated the large volumes of marking using electronic marking. Group assignment and individual assignments were also part of assessment. Lecturers used 
Moodle, Blackboard and virtual classroom to engage students and to facilitate learning. Even though the responsibility of learning is placed in student that is student centred teaching, the study emphases that it is the responsibility of the lecturers to develop effective teaching methods in engaging students in large classes. The results of these studies proves that students prefer small classes for high rate of engagement and involvement which result in active learning (Wood \& Tanner 2012).

In view of the findings alluded above about challenges of large classes, this has been the case at the Central University of Technology, Free State. In our faculty, Humanities first-year intake has increased tremendously and this has put pressure on teaching and learning. From our experience a large class ranges from 120 to 250 students in one seating. Lecturers in the Department of Education and Professional Studies provide service to other Departments like Languages, Mathematics, Economic and Management Sciences and find themselves teaching on average five subjects with more or less 800 students on average in a semester. This has resulted not having enough accommodation and lack of structure in the lecture rooms to cater for this large number of students. There have been situations whereby students will seat on the floor in a lecture room. Other challenges have been noise, disruptive classes, distractions, limited resources, lack of interaction, poor discussions, and large volume of marking which have a great impact on delivering quality education.

It has become apparent from the discussion above that large classes pose challenges in higher education institutions in different countries. Our institution is no exception, hence the need to undertake this study to uncover the challenges experienced by the students who are taught in such classes as well as the strategies that lecturers have devised in promoting and sustaining student participation and engagement in large classes.

\subsection{Student Engagement}

\section{Definitions of student engagement}

In educational settings, student engagement is defined as the 'time and effort students devote to educationally purposeful activities' (Australian Council for Educational Research, 2010b).

Student engagement describes or deals with meaningful student involvement throughout the learning environment. It talks to the relationship between the student and different elements of the learning environment such as peers, support staff, instruction and the curriculum. Student engagement is, therefore, a multidimensional construct, that can be measured to show the relationship among all these elements (Fredricks, Blumenfeld, and Paris, 2004) 
Taking the argument, further, Trowler (2010:2) argues that student engagement is concerned with the interaction between time, effort and other relevant resources invested by both students and their institutions. All these are intended to make the best of the student experience by enhancing their learning outcomes, development and performance. In so doing, the reputation of the institution is also enhanced.

\section{Definitions of student engagement}

In educational settings, student engagement is defined as the 'time and effort students devote to educationally purposeful activities' (Australian Council for Educational Research, 2010b).

Student engagement describes or deals with meaningful student involvement throughout the learning environment. It talks to the relationship between the student and different elements of the learning environment such as peers, support staff, instruction and the curriculum. Student engagement is, therefore, a multidimensional construct, that can be measured to show the relationship among all these elements (Fredricks, Blumenfeld, and Paris, 2004)

Taking the argument, further, Trowler (2010:2) argues that student engagement is concerned with the interaction between time, effort and other relevant resources invested by both students and their institutions. All these are intended to make the best of the student experience by enhancing their learning outcomes, development and performance. In so doing, the reputation of the institution is also enhanced.

\section{Dimensions of student engagement}

Fredricks at al (2004, 62-63), identify three dimensions to student engagement, namely, behavioural, emotional and cognitive engagement. Behavioural engagement is where students comply with behavioural norms, such as attendance and involvement, and would demonstrate the absence of disruptive or negative behaviour. Emotional engagement means that students who engage emotionally experience affective reactions such as interest, enjoyment, or a sense of belonging. Cognitive engagement implies that students invest time in their learning, and would go beyond the set requirements, and would relish challenge. Student engagement is a function of both the individual and the construct. It varies in intensity and duration. For example, a student may feel very engaged in one semester but not so much the next; another student might enjoy some of his or her classes but be bored in others. Student engagement is increasingly viewed as one of the keys to addressing problems such as low achievement, boredom and alienation, and high dropout rates.

Students can engage positively or negatively on any of the three dimensions, depending on the situation. 


\section{Types of student engagement}

Coates (2007) gives the typology of student engagement as illustrated in Figure 1. According to Coates, student engagement is divided into four types represented by four quadrants. These are, collaborative, intense, passive and independent types or forms of student engagement.

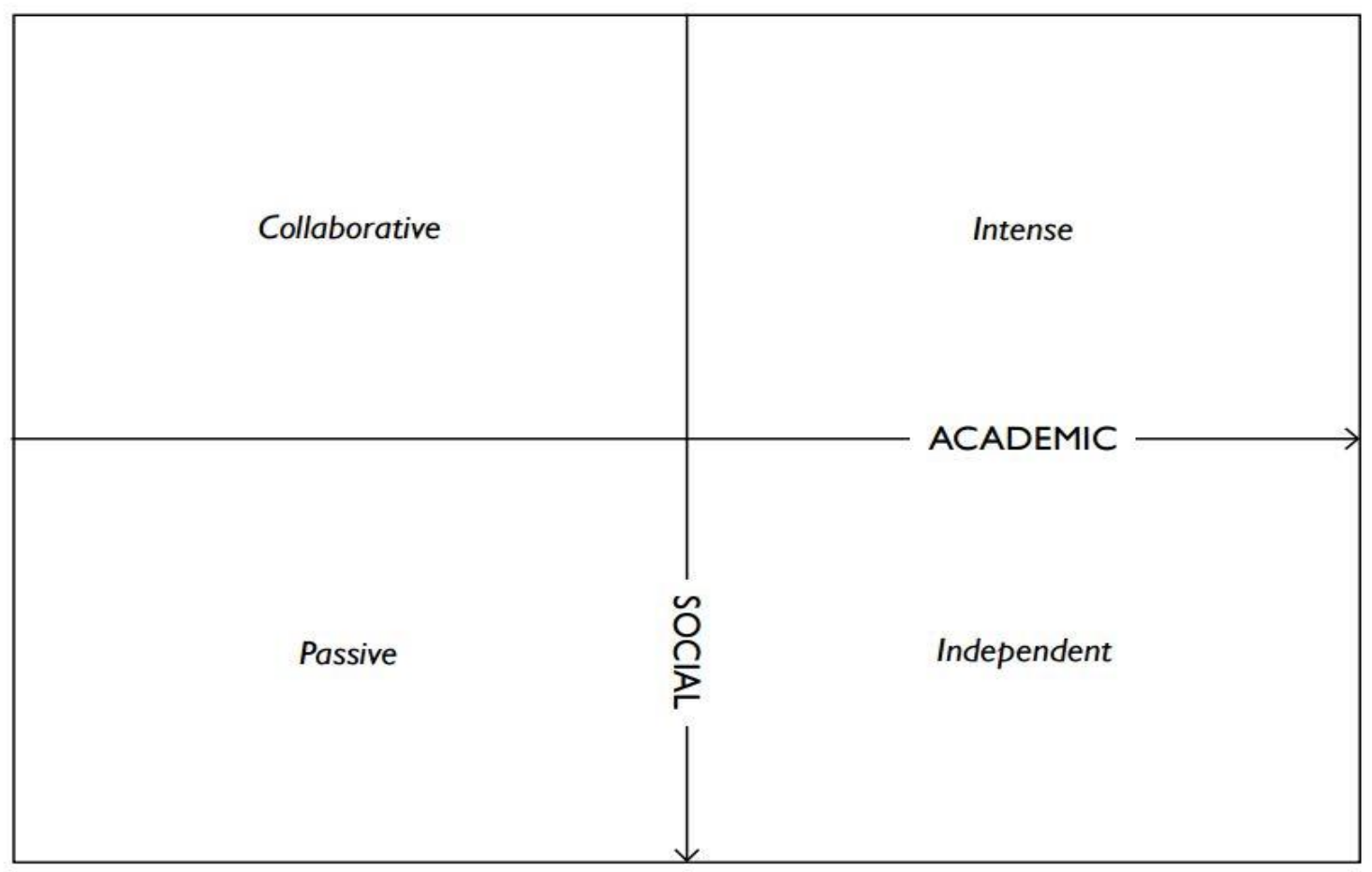

\section{Intense}

According to Coates (2007: 132-133) students who fall in this category of engagement are those who are highly engaged or involved with their studies. These students view their teachers as approachable, and consequently, their learning environment as responsive, supportive and challenging.

\section{Independent}

Students who display an independent style of engagement are those that show a more academically orientated and less socially orientated approach to study. Such students see themselves as participants in a supportive learning community, and see staff as approachable and responsive to their needs. These students value student reflection and feedback. They are however less collaborative with other students (Coates, 2007, 133-134). 


\section{Collaborative}

Students in this category of engagement tend to favour the social aspects of university life and work, as opposed to the more purely cognitive or individualistic forms of interaction. Student engagement reflects students' feelings within their university communities, particularly by participating in broad beyond-class talent development activities and interacting with staff and other students (Coates, 2007, 134).

\section{Passive}

These students rarely participate in the only or general activities and conditions linked to productive learning (Coates, 2007, 134).

What does this typology tell us? It shows that students are different and will respond to situations differently. Hence teachers and teacher educators should know how best to engage their learners or students so that no one is left behind. How do we engage all students in large classes?

\section{AIM OF THE STUDY AND RESEARCH QUESTIONS}

The aim of the study was to identify problems students and lecturers experience in large classes as well as effective strategies that lecturers have devised in promoting and sustaining student participation and engagement in these large classes.

The study sought to answer the following research questions:

1. What problems do students experience in being taught in large classes at this particular institution?

2. What problems do lecturers experience in teaching large classes at this particular institution?

3. What teaching strategies do lecturers use in teaching large classes?

4. Do teaching strategies used by lecturers in such large classes promote student participation and engagement?

5. What assessment methods do lecturers use to assess students in large classes?

6. How can lecturers be supported to improve on their skills in promoting and sustaining student participation and engagement in large classes? 


\section{RESEARCH METHODOLOGY}

\subsection{Research design}

This an exploratory case study of first year university students in the Free State province of the Republic of South Africa.

\subsection{Participants}

The participants were 248first-year students from four Departments of the Faculty of Humanities of this particular institution, as well as eight lecturers involved in the teaching of compulsory Educational Foundations modules, where there are large classes. The four departments from which the participants were drawn were: Languages, Natural Sciences, Mathematics,and Economic and Management Sciences (EMS).

\subsection{Data collection instruments}

A self-constructed questionnaire was used to collect data from the students while semi-structured interviews were used to collect data from the lecturers. The questionnaire contained both closed and open-ended questions.

\subsection{Ethical issues}

Participation in the study was voluntary and permission of both the students and lecturers was sought. The aims and benefits of the study were explained to the participants.

\section{Data Analysis}

Quantitative data from the questionnaires were analysed and descriptive statistics were generated. Themes were drawn from the qualitative data obtained through the open-ended questions of the questionnaire as well as semi-structured interviews 


\section{Sample Profile of the respondents}

Table 1. Sample profile of respondents

\begin{tabular}{|c|c|c|c|c|c|}
\hline & \multicolumn{2}{|c|}{ Frequency } & \multicolumn{2}{|c|}{ Percentages } & Total \\
\hline Programme & Males & Females & Males & Females & \\
\hline Natural Sciences & 12 & 27 & $31 \%$ & $69 \%$ & 39 \\
\hline EMS & 28 & 40 & $41 \%$ & $59 \%$ & 68 \\
\hline Languages & 36 & 66 & $36 \%$ & $64 \%$ & 102 \\
\hline Mathematics & 21 & 18 & $54 \%$ & $46 \%$ & 39 \\
\hline Total & 97 & 151 & $40 \%$ & $60 \%$ & 248 \\
\hline
\end{tabular}

Table 1 shows that the majority of students in the sample came from Languages followed by Economic and Management Sciences. Generally, there are more students in the two programmes compared with the two other programmes. Sixty percent $(60 \%)$ of the respondents were females whilst $40 \%$ were males.

\section{FINDINGS - Quantitative Data on students}

\section{Learning environment}

To assess the students' experiences of their classroom or learning environment, responses were sought from three categories, namely, their perceptions of the teaching methods used, challengesthey faced, their perceptions of their participation and student-lecturer interactions.

Teaching Methods used by lecturers as perceived by the students

Respondents were requested to indicate the teaching methods used by the lecturers intheir classrooms. Their responses were measured on on a three point Likert type scale, where 1 stands for never used, 2 = seldom used, and 3 mostly used. The number 2 , is the median and therefore any number higher than 2 will indicate a positive response. 
Table 2: Teaching methods( $\mathrm{N}=248)$

\begin{tabular}{|l|l|l|l|l|l|l|}
\hline & & $\begin{array}{l}\text { Natural } \\
\text { Sciences } \\
\mathbf{N = 3 9}\end{array}$ & $\begin{array}{l}\text { Mathematics } \\
\mathbf{N = 3 9}\end{array}$ & $\begin{array}{l}\text { EMS } \\
\mathbf{N}=68\end{array}$ & $\begin{array}{l}\text { Languages } \\
\mathbf{N}=\mathbf{1 0 2}\end{array}$ & $\begin{array}{l}\text { Overall } \\
\text { Mean }\end{array}$ \\
\hline $\begin{array}{l}\text { Teaching } \\
\text { Method }\end{array}$ & Mean & Mean & Mean & Mean & \\
\hline 1. & Lecture Method & 2.69 & 2.36 & 2.60 & 2.67 & $\mathbf{2 . 5 8}$ \\
\hline 2. & $\begin{array}{l}\text { Question and } \\
\text { answer method }\end{array}$ & 2.69 & 2.59 & 2.53 & 2.62 & $\mathbf{2 . 6 1}$ \\
\hline 3. & $\begin{array}{l}\text { Discussion } \\
\text { groups }\end{array}$ & 2.10 & 2.10 & 1.88 & 2.15 & $\mathbf{2 . 0 6}$ \\
\hline 4. & Problem Solving & 2.41 & 2.72 & 2.04 & 2.19 & $\mathbf{2 . 3 4}$ \\
\hline 5. & Case Studies & 1.64 & 1.82 & 1.72 & 1.79 & $\mathbf{1 . 7 4}$ \\
\hline 6. & Projects & 2.33 & 2.10 & 2.26 & 2.31 & $\mathbf{2 . 2 5}$ \\
\hline 7. & $\begin{array}{l}\text { Presentations } \\
\text { by students }\end{array}$ & 2.31 & 2.21 & 2.33 & 2.21 & $\mathbf{2 . 2 7}$ \\
\hline 8. & $\begin{array}{l}\text { Power-point } \\
\text { presentations }\end{array}$ & 2.82 & 2.82 & 2.78 & 2.80 & $\mathbf{2 . 8 0}$ \\
\hline 9. & $\begin{array}{l}\text { Games and } \\
\text { Simulations }\end{array}$ & 1.44 & 1.36 & 1.30 & 1.18 & $\mathbf{1 . 3 0}$ \\
\hline 10 & Overall Mean & $\mathbf{2 . 2 7}$ & $\mathbf{2 . 2 3}$ & $\mathbf{2 . 1 6}$ & $\mathbf{2 . 2 1}$ & $\mathbf{2 . 2 2}$ \\
\hline
\end{tabular}

Table 2indicatesthatthe commonly used teaching strategies are the lecture method, question and answer method, and power-point presentations. Because the classes are large power-point presentations appear to be the best way of reaching out to all the students. Power-point presentations, however, support the lecture method. The teaching methods which were less used by the lecturers are discussion groups, case studies and presentation by students. The least used are games and simulations. Games and simulations appear difficult to use in the large classes like Languages and EMS.

\section{Challenges students experience in their classes}

The students' responses were again measured on a three point Likert type scale, where 1 stands for not a challenge, $2=$ to some extent and $=3$ to a great extent. Table 2 shows that the two most challenges experienced by students is overcrowding and noise across all disciplines. Although the means are in some instances lower than 2, they are still close to 2 , which indicates that there is a problem. 
Table 3 Challenges students experience in their classes $(\mathrm{N}=248)$

\begin{tabular}{|c|c|c|c|c|c|c|}
\hline & & $\begin{array}{l}\text { Natural } \\
\text { Science } \\
\mathrm{N}=39\end{array}$ & $\begin{array}{l}\text { Mathematics } \\
\mathrm{N}=39\end{array}$ & $\begin{array}{l}\text { EMS } \\
N=68\end{array}$ & $\begin{array}{l}\text { Languages } \\
\mathrm{N}=102\end{array}$ & $\begin{array}{l}\text { Overall } \\
\text { Mean }\end{array}$ \\
\hline & & Mean & Mean & Mean & Mean & \\
\hline 1. & $\begin{array}{l}\text { Inadequate } \\
\text { teaching and } \\
\text { learning facilities }\end{array}$ & 1.79 & 1.69 & 1.74 & 1.68 & 1.73 \\
\hline 2. & $\begin{array}{l}\text { Teaching and } \\
\text { learning facilities } \\
\text { of a poor quality }\end{array}$ & 1.49 & 1.49 & 1.57 & 1.51 & 1.52 \\
\hline 3. & $\begin{array}{l}\text { Inability of the } \\
\text { lecturer to teach in } \\
\text { a manner that } \\
\text { could be } \\
\text { understood by all } \\
\text { students }\end{array}$ & 1.97 & 1.87 & 1.81 & 1.86 & 1.88 \\
\hline 4. & Overcrowding & 2.33 & 2.36 & 2.07 & 2.38 & 2.29 \\
\hline 5. & $\begin{array}{l}\text { Lack of class } \\
\text { discussions }\end{array}$ & 1.92 & 1.92 & 2.08 & 1.97 & 1.97 \\
\hline 6. & $\begin{array}{l}\text { Lack of interaction } \\
\text { among students }\end{array}$ & 1.87 & 1.87 & 1.97 & 2.00 & 1.93 \\
\hline 7. & $\begin{array}{l}\text { Lack of interaction } \\
\text { of the lecturer with } \\
\text { individual students }\end{array}$ & 1.90 & 1.87 & 1.88 & 2.00 & 1.91 \\
\hline 8. & Noise & 2.13 & 2.15 & 2.19 & 2.06 & 2.13 \\
\hline 9. & $\begin{array}{ll}\text { Disruptive } & \text { student } \\
\text { behaviour } & \text { in } \\
\text { classes } & \end{array}$ & 1.95 & 1.82 & 1.91 & 1.81 & 1.87 \\
\hline & Average Mean & 1.92 & 1.69 & 1.91 & 1.91 & 1.86 \\
\hline
\end{tabular}

Student participation and relationship with the lecturer

The students were requested to rate their participation in the classroom. Their responses were measured on a three point Likert type scale ranging from $1=$ (No participation), $2=$ (sometimes) and $3=$ (Always). 
Table 4: Student participation and relationship with the lecturer( $\mathrm{N}=248)$

\begin{tabular}{|c|c|c|c|c|c|c|}
\hline & & $\begin{array}{l}\text { Natural } \\
\text { Science } \\
\mathrm{N}=39\end{array}$ & $\begin{array}{l}\text { Mathematics } \\
\mathrm{N}=39\end{array}$ & $\begin{array}{l}\text { EMS } \\
\mathrm{N}=68\end{array}$ & $\begin{array}{l}\text { Languages } \\
\mathrm{N}=102\end{array}$ & $\begin{array}{l}\text { Overall } \\
\text { Mean }\end{array}$ \\
\hline & & Mean & Mean & Mean & Mean & \\
\hline 1. & $\begin{array}{l}\text { I am able to } \\
\text { participate in class } \\
\text { activities }\end{array}$ & 1.77 & 1.90 & 2.38 & 2.06 & 2.03 \\
\hline 2. & $\begin{array}{l}\text { I interact with the } \\
\text { lecturer in class }\end{array}$ & 2.13 & 2.44 & 2.39 & 2.20 & 2.29 \\
\hline 3. & $\begin{array}{l}\text { I have a one-on- } \\
\text { one relationship } \\
\text { with the lecturer }\end{array}$ & 1.38 & 1.23 & 1.37 & 1.45 & 1.36 \\
\hline 4. & $\begin{array}{l}\text { Lecturers know } \\
\text { me by name }\end{array}$ & 1.56 & 1.51 & 1.44 & 1.52 & 1.51 \\
\hline 5. & $\begin{array}{l}\text { I feel isolated in } \\
\text { the classroom }\end{array}$ & 1.55 & 1.54 & 1.52 & 1.35 & 1.49 \\
\hline 6. & $\begin{array}{l}\text { I contribute to } \\
\text { discussions in the } \\
\text { classroom }\end{array}$ & 2.26 & 2.49 & 2.30 & 2.38 & 2.36 \\
\hline 7. & $\begin{array}{l}\text { I am able to ask } \\
\text { questions in the } \\
\text { classroom }\end{array}$ & 1.90 & 2.08 & 2.01 & 1.94 & 1.98 \\
\hline 8. & $\begin{array}{l}\text { I am allowed to } \\
\text { take risks and } \\
\text { make errors in the } \\
\text { classrooms }\end{array}$ & 2.67 & 2.67 & 2.73 & 2.76 & 2.71 \\
\hline 9. & $\begin{array}{l}\text { I am able to share } \\
\text { information in the } \\
\text { classroom with } \\
\text { other students }\end{array}$ & 2.56 & 2.64 & 2.66 & 2.60 & 2.62 \\
\hline & Average Mean & 2.12 & 2.25 & 2.28 & 2.18 & 2.21 \\
\hline
\end{tabular}

Although the classes are large students can still participate, make contributions, take risks in the classroom, interact with the lecturers and share information with other students in class. There are however feelings of isolation for some students as the table shows. 


\section{Assessment}

The perception of students with regard to assessment were measured using a 3 point Likert scale. The questions focused on marking scripts, feedback and assessment method. The response mode used varied from one (1) to three (3); One (1) means not at all, two (2) means sometimes and three (3) means always.

Table 5: Assessment ( $\mathrm{N}=248)$

\begin{tabular}{|c|c|c|c|c|c|c|}
\hline & & $\begin{array}{l}\text { Natural } \\
\text { Science }\end{array}$ & Mathematics & EMS & Languages & $\begin{array}{l}\text { Overall } \\
\text { Mean }\end{array}$ \\
\hline & Assessment & & & & & \\
\hline 1. & $\begin{array}{l}\text { Scripts are } \\
\text { marked fairly }\end{array}$ & 2.49 & 2.51 & 2.26 & 2.41 & 2.42 \\
\hline 2. & $\begin{array}{l}\text { We get feedback } \\
\text { on time after } \\
\text { writing the test }\end{array}$ & 2.18 & 2.26 & 2.26 & 2.43 & 2.28 \\
\hline 3. & $\begin{array}{l}\text { We get feedback } \\
\text { on time after } \\
\text { submitting the } \\
\text { assignments }\end{array}$ & 1.97 & 2.21 & 2.12 & 2.23 & 2.13 \\
\hline 4. & $\begin{array}{l}\text { Examinations are } \\
\text { challenging }\end{array}$ & 2.15 & 2.05 & 1.96 & 2.04 & 2.05 \\
\hline 5. & 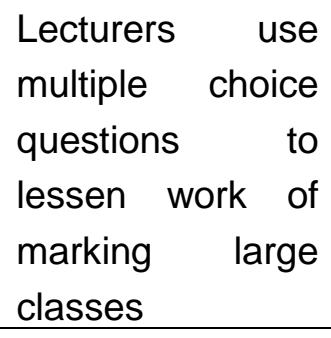 & 1.95 & 2.05 & 2.06 & 1.88 & 1.99 \\
\hline \multirow[t]{2}{*}{6.} & $\begin{array}{l}\text { Lecturers prefer } \\
\text { group } \\
\text { assignment to } \\
\text { individual } \\
\text { assignments. }\end{array}$ & 2.38 & 2.56 & 2.12 & 2.31 & 2.34 \\
\hline & Average Mean & 2.19 & 2.17 & 2.13 & 2.21 & 2.18 \\
\hline
\end{tabular}

Although the classes are large the students view assessments in a positive manner. Their scripts are marked fairly, feedback is received on time after writing tests and assignments. Lecturers seem to prefer group assignments to individual assignments.Multiple choice questions are sometimes used. 


\section{Qualitative Data on students}

The open-ended questions were used to probe further on the challenges created by large classes, possible ways of engaging them in class, and what they have learnt from being taught in large classes.

Challenges encountered in large classes

The students in the study reported on the following challenges:

- Too much noise

- Constant distractions caused by studentsmoving up and down in class

- Inadequate resources like chairs, tables, air conditioners and micro phones

- Inability of lecturers to reach each student, no individual attention

- Disruptive behavior of some students -students do not cooperate in class

The comments support the questionnaire data wherestudents indicated that challenges they have experienced in the learning environment are noise, lack of resources and lack of interaction of the lecturer with individual students (see Table 2). This shows that student performance, achievement and participation is affected by the above mentioned factors because student participation is depended upon interaction between time, effort, relevant resources, peers, instruction and curriculum to enhance the learning (Fredrickset al, 2004 \& Trowler 2010). Frediricks et al (2004) further posited that behavioural engagement is the absence of disruptive or negative behaviour, whereby students can engage negatively if disruptions are present in the classroom environment.

\section{Encouraging students' engagement in a large classroom}

The students have different views regarding the different ways in which participation and engagement can be encouraged in a large classroom. The comments included:

Encouraging discussions, building a positive rapport with students, dividing the classes into groups, giving all students a chance to answer questions, and that the university should take into consideration the size and shape of the university when admitting students. While the latter is reasonable it acts against the principle of increasing access to university for all students. A few excerpts are included in the paper. 
- "Encourage active study discussions in the classrooms and presentations more frequently. Build a positive communication between students so that they can be comfortable in the classroom".

- "Divide the classes into groups".

- "Lectures should stop pointing at their favorites should give everyone a chance".

- "By the use of tablets and clickers".

- "Create an online discussion group so that everyone can participate".

- "The university should stop registering many students knowing very well that the classes are not big enough".

Students indicated that though lectures used technology in the classroom, they need to explore other strategies like online discussions as observed by (Moodley 2015). Lecturers should also maintain relationship with the students to enhance teaching and learning that is the collaborative style of engagement (Coates, 2007).

Benefits of attending large classes

These are the benefits that the students have mentioned:

- Diversity in the classroom in terms of culture, language, race and personalities

- Able to share knowledge

- Able to listen and respect other people's views

\section{Qualitative data from interviews with lecturers}

Eight (8) lecturers who took part in the study teach on average five subjects with more or less 800 students on average in a semester. The participants reported that they consider more than 100 students in one sitting as a large class and prefer to teach not more than fifty (50) students at a time.

In order for lecturers to succeed in large classes they need to be exposed to a variety of technologies as well as different teaching modes to better engage students (Moodley 2015; Hornsby at al. 2013; Mulryan- Kyne 2010). 
Challenges faced by lecturers in teaching large classes

The lecturers identified the following challenges:

- Resource constraints (due to overcrowding)

- Poor class attendance (as it is difficult to keep track of students; signing the attendance registers is time consuming and some students sign for their friends. Verifying the attendance list against students on attendance becomes a problem).

- Lack of student motivation

- Lack of discipline

- Delays in marking students' work

- No collaboration among lecturers

- Unable to explore different teaching methods in class

- Lack of interaction/communication

- Poor participation of students in class

- Limited space

Large classes and the quality of teaching

The lecturers were asked to indicate if large classes affected the quality of their teaching. All the respondents indicated that large classes have affected the quality of teaching and they are unable to be creative in lesson design and presentations, hence it is difficult to engage students. They are unable to reach all the students and give individual attention, that clearly shows active learning is limited.Wood and Tanner (2012) have argued that engagement and involvement in the classroom result in active learning.

The following excerpts from lecturers illustrate how their quality of work has been affected their teaching and learning:

"Most of the times I just make use of the lecture method accompanied by PowerPoint".

"I am unable to engage all the students".

"I am unable to explore different teaching strategies". 
"One cannot give individual attention".

"Marking is difficult".

"Students miss classes and one is unable to monitor attendance".

"Students disappear in the crowd and don't get involved in tasks".

Assessment

In terms of assessment, lecturers have shown that they are able to plan assessment effectively and the main consideration is the administrative difficulties in terms of marking and entering the marks on the system. The assessment is spread evenly over the course of the semester and two formative assessments and one summative evaluation are considered for thestudents'progress.

Mostly, lecturers used tests and group assignments to assess the students. This means that lecturers need to explore more strategies of assessment to test the ability of students.

\section{Effective strategies to promote and sustain student participation and engagement}

In large classes, it is important to foster interaction and to create an environment for student participation. In order to achieve this, lecturers must make use a variety of methods or strategies (Moodley 2015; Hornsby at al. 2013; Mulryan- Kyne 2010). The lecturers identified the following strategies that they have devised in promoting and sustaining student participation:

- Group teaching

- Group marking

- Classes being divided into groups

- Use of visual aids like Videos and PowerPoint

- Using Blackboard (Ethuto)

- Group work outside the classroom 


\section{DISCUSSION}

The study sought to answer the following research questions:

1. What problems do students experience in being taught in large classes at this particular institution?

2. What problems do lecturers experience in teaching large classes at this particular institution?

3. What teaching strategies do lecturers use in teaching large classes?

4. Do teaching strategies used by lecturers in such large classes promote student participation and engagement?

5. What assessment methods do lecturers use to assess students in large classes?

6. How can lecturers be supported to improve on their skills in promoting and sustaining student participation and engagement in large classes?

1. What problems do students experience in being taught in large classes at this particular institution?

Large classes created problems for the first year students in this study. The findings support other studies that argue that participation of students in large classes is negatively affected. In a study conducted at the University of Limpopo and University of Zululand, Moodley (2015) found that large classes are prevalent in first year courses across disciplines. Cash et al (2017) made a similar observation about the increase of enrolments in undergraduate classes. In these studies, lecturers resorted to using the traditional lecture method to teach students. In this study as seen in Table 2, the teaching methods mainly used is the lecture method, question and answer method and power-point presentations. This is problematic as these are the students who are supposed to be helped to ease the transition from school to tertiary education.

The main challenge faced by the students being taught in large classes was overcrowding and noise as seen in Table 3. This was supported by the student responses from the open-ended questions. The students also indicated that some of the classes lacked the necessary resources. For example, in some instances lecturers do not have laptops and then the use of power-point presentations become impossible.

This situation of large classes, overcrowding and unbearable noise levels, has affected student participation as observed from Table 4 . There is participation but students want more participation and how they relate with the lecturers. Statements 
such as: one-on -one relationship with the lecturer, lecturer knows the student by name, have low scores.

Coming to assessment of their work, students appeared happy with how their scripts were marked and the feedback they got from the lecturers. The use of multiple choice questions here was not so much of an issue. This could be linked to the nature of the subjects taught by the lecturers concerned.

\section{What problems do lecturers experience in teaching large classes at this particular institution?}

From the interviews conducted with lecturers, the lecturers complained bitterly about resource constraints due to overcrowding. They experience lack of discipline and consequently problems related to classroom management. They struggle to get motivate students and get them to participate in class. Although the students did not complain about the marking of their scripts and time delays in getting feedback, the lecturers felt that there are time delays during marking.

\section{What teaching strategies do lecturers use in teaching large classes?}

Large classes have forced lecturers to use team teaching. Large classes are divided into groups and five to six lecturers teach the students at the same time. This has also its problems as there has to be co-operation and team spirit among the lecturers sharing a subject. They have to move at the same pace as the tests and group assignments have to be done at the same time. This sort of erodes one's initiative and creativity.

From the students' perspective lecturers use a variety of teaching methods in class, varying from the traditional teaching in front of class, to group discussion, student presentations, projects, with the use of technology receiving the most positive response.

However, lecturers should do more to embrace games and simulations, as well as case studies as methods of teaching to engage learners more in their teaching and learning experience.

4. Do teaching strategies used by lecturers in such large classes promote student participation and engagement?

Student participation and engagement occurs to a limited extent in group activities and group presentations

5. What assessment methods do lecturers use to assess students in large classes? 
Group assignments are used. Individual tests are still used to comply with university regulations. To meet the deadlines required by the Examinations section of the University, the lecturers use team marking. They come together as a group and mark the scripts together. This practice has its own challenges as all the lecturers have to pull their weight to ensure that marking is done properly. This needs a lot of coordination as the marks have to be checked, arranged in a particular order and then captured into the mark sheets before being submitted to Examinations Department. This is an administrative function which takes a lot of time.

6. How can lecturers be supported to improve on their skills in promoting and sustaining student participation and engagement in large classes?

What needs to be done is for the institution to provide more classes, employ more staff and train lecturers in large class pedagogies as large classes have come to stay.

\section{CONCLUSION}

Teaching large classes poses many problems which impact teaching and learning negatively. This study was, therefore, aimed to look at the challenges lecturers and first-year university studentsexperience in large classes, and the strategies lecturers have devised in promoting and sustaining student participation and engagement in their classes. The findings have uncovered that both the lecturers and first-year students have agreed that classes at CUT are overcrowded and too big as a result inhibit active engagement learning. Nevertheless, there are innovative teaching and assessment strategies that have helped both lecturers and students to cope with large classes. Students made insightful comments regarding the challenges and benefits of attending large classrooms. Participation can also be facilitated by using different strategies and a variety of technology to enhance teaching and learning. To improve teaching in large classes there should be a system in place by the university as part of a solution to help lectures deal with large classes and engage students in learning. The lecturers need to learn more about interventions and systematic programs that are needed and effective in large classes and appropriate for all students. Lecturers should make use of engaging pedagogies such as electronic, active, intense, independent and collaborative strategies to facilitate learning. Teaching large classes poses many problems which impact teaching and learning negatively, therefore it is important to have systematic programs to help eliminate the problem. 


\section{REFERENCES}

Australian Council for Educational Research 2010bAustralian Council for Educational Research. 2010b. "Doing more for learning: Enhancing engagement and outcomes". In Australasian Student Engagement Report, Camberwell: ACER. [Google Scholar], 1).

Carpenter, J.M., 2006. Effective teaching methods for large classes. Journal of Family \& Consumer Sciences Education, 24(2), pp.13-23.

Cash CB, Letargo J, Graether SP, Jacobs SR. An Analysis of the Perceptions and Resources of Large University Classes. CBE-Life Sciences Education. 2017 Jun 20; 16(2):ar33.

Coates, H. (2007) A Model of Online and General Campus-Based Student Engagement.Assessment and Evaluation in Higher Education. 32 (2), pp. 121-141.

Cooper, J.L. and Robinson, P., 2000. The argument for making large classes seem small. New directions for teaching and learning, 2000(81), pp.5-16.

Fredricks, J., Blumenfeld, P., \& Paris, H. (2004). School engagement: Potential of the concept, state of the evidence. Review of Educational Research, 74, 59-109.

Hornsby, D.J., Osman, R. and De Matos-Ala, J., 2013. Large-class pedagogy: Interdisciplinary perspectives for quality higher education. AFRICAN SUN MEDIA.

Jaffer, S., Ng'ambi, D. and Czerniewicz, L., 2007. The role of ICTs in higher education in South Africa: One strategy for addressing teaching and learning challenges. International journal of Education and Development using ICT, 3(4).

Koenig, L.B, Gray, M, Lewis, S. and Martin, S. 2015. Students Preferences for small and large classes. International Journal of Humanities and Social Science, 5(1).

Maree, K. 2007. First Steps in Research. Pretoria: Van Schaik.

McMillan, J.H. \& Schumacher, S. 2006. Research in Education. $6^{\text {th }}$ ed. Boston: Pearson.

Moodley, P., 2015. Student overload at university: large class teaching challenges: part 1. South African Journal of Higher Education, 29(3), pp.150-167.

Mulryan-Kyne, C., 2010. Teaching large classes at college and university level: Challenges and opportunities. Teaching in Higher Education, 15(2), pp.175-185.

Pike, G. R., and Kuh, G. D. (2005a). A Typology of Student Engagement for American Colleges and Universities. Research in Higher Education, 46(2): 185-209. 
Onwu, G. and Stoffels, N., 2005. Instructional functions in large, under-resourced science classes: perspectives of South African teachers: research article: general. Perspectives in Education, 23(1), pp.79-91.

Wood, W.B. and Tanner, K.D., 2012. The role of the lecturer as tutor: doing what effective tutors do in a large lecture class.CBE-Life Sciences Education, 11(1), pp.3-9. 